\title{
Recent advances in the molecular mechanism of sex disparity in hepatocellular carcinoma (Review)
}

\author{
YANMENG LI ${ }^{1,2}$, ANJIAN XU ${ }^{1,2}$, SIYU JIA ${ }^{1,2}$ and JIAN HUANG ${ }^{1,2}$ \\ ${ }^{1}$ Experimental Center, Liver Research Center, Beijing Friendship Hospital, Capital Medical University; \\ ${ }^{2}$ National Clinical Research Center for Digestive Disease, Beijing 100050, P.R. China
}

Received July 5, 2018; Accepted January 25, 2019

DOI: $10.3892 / 01.2019 .10127$

\begin{abstract}
Hepatocellular carcinoma (HCC) is more frequently observed and aggressive in men compared with women. Increasing evidence demonstrates that the sex disparity appears to be mediated by the stimulatory effects of androgens and the protective effects of estrogen in the development and progression of HCC. In the past few decades, studies on the sex difference of HCC mainly focused on the effect of sex hormones on the transactivation of hepatitis $\mathrm{B}$ virus $\mathrm{X}$ protein and the release of inflammatory cytokines, and these studies have further intensified in recent years. Sex hormones are also involved in genetic alterations and DNA damage repair in hepatocytes through binding to their specific cellular receptors and affecting the corresponding signaling pathways. Furthermore, the theory of sex chromosomes participating in HCC has been considered. The present review discussed the recent advances in the molecular mechanisms of sex disparity in HCC, with the aim of improving the understanding of the underlying critical factors and exploring more effective methods for the prevention and treatment of HCC.
\end{abstract}

\section{Contents}

1. Introduction

2. Estrogen may serve an inhibitory role in sex disparity in HCC via miRNAs, DNA repair and obesity associated pathway

3. Androgen/AR serves a role in promoting sex disparity in $\mathrm{HCC}$

4. Sex chromosomes are involved in sex disparity in HCC

5. Conclusions

Correspondence to: Professor Jian Huang, Experimental Center, Liver Research Center, Beijing Friendship Hospital, Capital Medical University, 95 Yong-An Road, Beijing 100050, P.R. China

E-mail: huangj1966@hotmail.com

Key words: hepatocellular carcinoma, sex disparity, molecular mechanism, estrogen, androgens, chromosome

\section{Introduction}

Hepatocellular carcinoma (HCC) is the most common primary malignant tumor of the liver and the second most common cause of cancer-associated mortality worldwide (1). The associated risk factors for HCC have been established and include viral hepatitis, alcohol consumption, nonalcoholic steatohepatitis, genetic metabolic diseases and environmental exposure $(2,3)$. However, comparative studies and data have identified that a marked feature of HCC is that males have a higher incidence and worse prognosis compared with females in low- and high-incidence areas (4). The American Cancer Society estimated the numbers of new liver cancer cases that occurred in the United States in 2017 to be 40,710 (29,200 males and 11,510 females), with 28,920 mortalities (19,610 males and 9,310 females) (5). In China the most recent statistics indicate an incidence rate of 466,100 (343,700 males and 122,300 females), with 422,100 mortalities (310,600 males and 111,500 in females) (6). The sex disparity of HCC has demonstrated that the ratio of estrogen and testosterone levels may be associated with the initiation and progression of HCC, suggesting that active estrogen- and androgen-mediated signaling pathways may regulate the risk of HCC $(7,8)$. In recent years, increasing attention has been focused on the genetic alterations of sex chromosomes, which may be responsible for the sex disparity in HCC (9-11). Considerable efforts have been exerted in exploring the molecular mechanisms involved in the sex disparity in HCC (7-9). The current article reviewed the molecular mechanisms underlying the involvement of the sex hormones, including androgens and estrogens and their corresponding receptors, as well as of the sex chromosomes in the pathogenesis of HCC.

2. Estrogen may serve an inhibitory role in sex disparity in HCC via miRNAs, DNA repair and obesity associated pathways

In contrast to the tumor-promoting activity of the androgens, the preventive and inhibitory effects of estrogen have been epidemiologically demonstrated by studies revealing an increased incidence of HCC following the menopause (12-14). This is consistent with animal studies in which treatment with estrogen decreased the incidence and metastasis of HCC, and ovariectomy increased susceptibility to HCC in female mice (15). In 
past studies, chronic inflammation was a major contributor to tumorigenesis and estrogen modulated inflammatory tumor microenvironment via suppression of pro-inflammatory cytokines (16-20). In addition, the metabolism of $17 \beta$-estradiol (E2) is involved in the sex disparity in HCC. Overexpression of liver-specific cytochrome P450 1A2 (CYP1A2) markedly contributed to the inhibitory effect in HCC cells by converting E2 to the cytotoxic 2-methoxyestradiol $(21,22)$.

However, in addition to the frequently reported molecular mechanisms underlining the role of estrogen in the gender disparity of $\mathrm{HCC}$, recent studies have proposed that estrogen may serve an inhibitory role in sex disparity of HCC via micro RNA, DNA repair and obesity associated pathways (23-25).

Estrogen receptors. With different intracellular expression patterns in the nucleus, cytoplasm or membrane, estrogen is involved in various cellular processes including proliferation, survival, apoptosis and differentiation through the estrogen receptors (ERs) (26). ER $\alpha$ and ER $\beta$, two forms of ERs, share significant structural homology and ligand binding properties, and yet function very differently. As in breast cancer, aberrant increases in $E R$ gene expression have been reported in liver tumors compared with normal or non-tumorous liver in patients with HCC (27). ER $\alpha$-mediated inhibition of nuclear factor- $\kappa \mathrm{B}$ binding activity is a pivotal event in the process of inhibiting tumor formation (28). A previous study suggested that the malignant behavior of HCC cells is markedly suppressed by treatment with E2 through the E2/ER $\beta /$ mitogen-activated protein kinase (MAPK) pathway-mediated increase of the nucleotide-binding domain, leucine-rich-containing family, pyrin domain-containing-3 inflammasome (29). ER $\alpha$ transfection effectively promotes the upregulation of estrogen to protein tyrosine phosphatase receptor type O (PTPRO) in HCC cell lines and it is positively correlated with the expression of $\mathrm{ER} \alpha$ and PTPRO in liver tissues (30). It has also been identified that estrogen functions as a suppressor of macrophage alternative activation and tumor progression by preventing $\mathrm{ER} \beta$-adenosine triphosphate $5 \mathrm{~J}$ interaction, thus inhibiting the Janus kinase 1/signal transducer and activator of transcription 6 signaling pathway (Fig. 1) (31). Other studies revealed that ER inhibited the proliferation and invasion of human HCC cells by decreasing the transcription of metastatic tumor antigen 1 and peroxisome proliferator activated receptor $\gamma(32,33)$.

MicroRNAs (miRNAs). miRNAs are small noncoding RNAs of 20 nucleotides that bind to conserved 3'-untranslated region sequences of their target mRNAs and induce the inhibition of their translation (34). Thereby miRNAs regulate gene transcription and expression to modulate important physiological functions $(35,36)$. miRNAs serve a vital role in numerous pathological events and in the cell response to various stresses (35). In the hepatocarcinogenic process, numerous miRNAs show abnormal expression in $\mathrm{HCC}$ tissues compared with paired adjacent nontumorous tissues. Therefore, miRNAs are recognized as a group of host genetic factors associated with hepatocarcinogenesis (36-38). The cross-linking of some miRNAs with ER is involved in the sex difference in HCC. Zheng et al (22) concluded the correlation between some miRNAs and sex disparity in HCC, including miR-23a, miR-545 and miR-221. Other miRNAs associated with sex disparity in HCC will be discussed in the current review (Fig. 1). miR-21 exhibits reduced mRNA binding and silencing activity in healthy mouse liver, but its expression is significantly elevated in HCC (39). Teng et al (23) reported that dehydroepiandrosterone, a precursor for adrenal androgen biosynthesis, activates ER $\beta$ and androgen receptors and increases miR-21 transcription. On the contrary, E2 inhibits miR-21 expression via $\mathrm{ER} \alpha$ (23). The role of circulating miR-22, as an independent prognostic marker of poor clinical outcome, has been demonstrated by Cox regression analysis (40). Jiang et al (41) demonstrated that overexpression of miR-22 in male tumor-adjacent tissue was associated with downregulated ER $\alpha$ expression by targeting its 3'-untranslated region. miR-22 suppresses ER transcription and attenuates the protective effect of estrogen, eventually increasing interleukin (IL)-1 $\alpha$ expression. The persistently high level of IL-1 $\alpha$ may lead to compensatory proliferation and tumorigenesis (41). In addition, by comparing the expression pattern of miRNAs between male and female patients with HCC, miR-18a was identified to be increased in female HCCs. Furthermore, miR-18a targets the estrogen receptor 1 gene, which encodes the ER $\alpha$ protein, and prevents translation of ER, preferentially blocking the protective effects of estrogen and promoting the development of HCC in women (42). In addition, elevated p53 promotes miR-18a processing to decrease the expression level of ER $\alpha$ in female patients with HCC, thereby suppressing the tumor-protective function of the estrogen pathway (43). The production of estrogen is associated with steroidogenesis pathways, including steroidogenesis enzymes (44). However, to the best of our knowledge, there have been no reports regarding the interaction of miRNAs with steroidogenesis genes involved in sex disparity in HCC.

DNA damage repair. Genetic alterations and genomic instability, possibly resulting from unrepaired DNA lesions, are increasingly recognized as a common feature of human HCC $(45,46)$. In particular, next-generation sequencing technologies have revealed numerous genetic alterations, including recurrently mutated genes and dysregulated signaling pathways in HCC (45). Therefore, timely repair of DNA damage is necessary. However, whether DNA damage repair is involved in the sex disparity in HCC is largely unclear. The potential association between estrogen and genomic instability is worth exploring. Previous studies have reported the development of HCC from the aspects of DNA damage repair-associated genes, including poly (ADP-ribose) polymerase (PARP1), transcription factor IIH (TFIIH) and nicotinamide adenine dinucleotide (NADC) (47-49), which were associated with estrogen signaling pathways (49-51). The present review explored the roles of these DNA repair associated genes in the sex disparity of HCC (Fig. 2).

Poly(ADP-ribose) polymerase (PARP) 1.PARP1, a well-known DNA-binding enzyme, has a potential role in DNA repair, especially in triggering the base-excision repair process in the early stage of oxidative DNA damage repair (52). PARP1 is also involved in a variety of other biological processes, including transcriptional regulation, apoptosis, mitosis and protein degradation (53). The hepatitis B virus (HBV) core promoter region binds to PARP1 and inhibits the DNA repair capacity of 


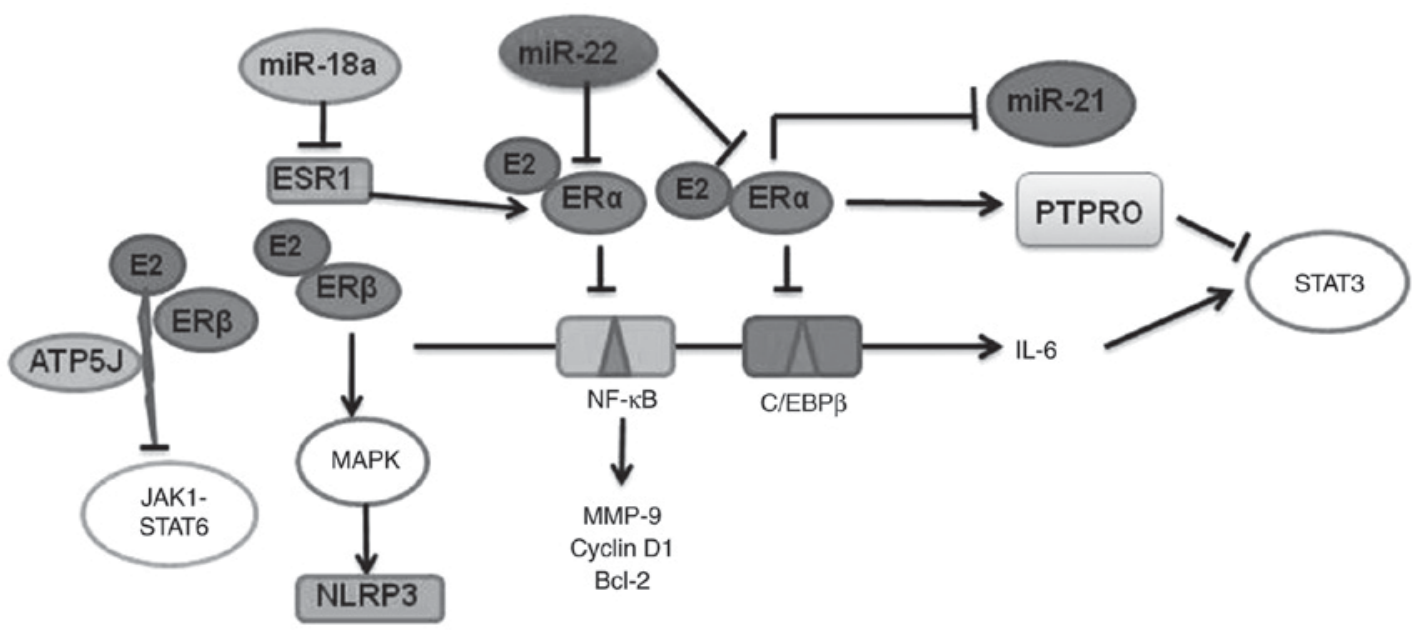

Figure 1. Estrogen serves an inhibitory role in the sex disparity in hepatocellular carcinoma by regulating inflammation and miRNAs. ER $\alpha$, estrogen receptor $\alpha$;

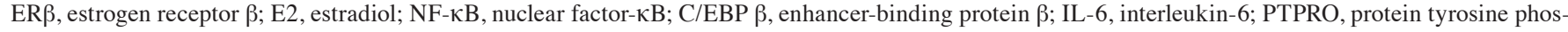
phatase receptor type O; STAT3, signal transducer and activator of transcription 3; MMP-9, matrix metalloproteinase-9; MAPK, mitogen-activated protein kinase; ATP5J, Adenosine triphosphate 5J; JAK1, Janus kinase 1; STAT6, signal transducer and activator of transcription 6; miR-21, microRNA-21; miR-22, microRNA-22; miR-18a, microRNA-18a; Bcl-2, B-cell lymphoma 2.

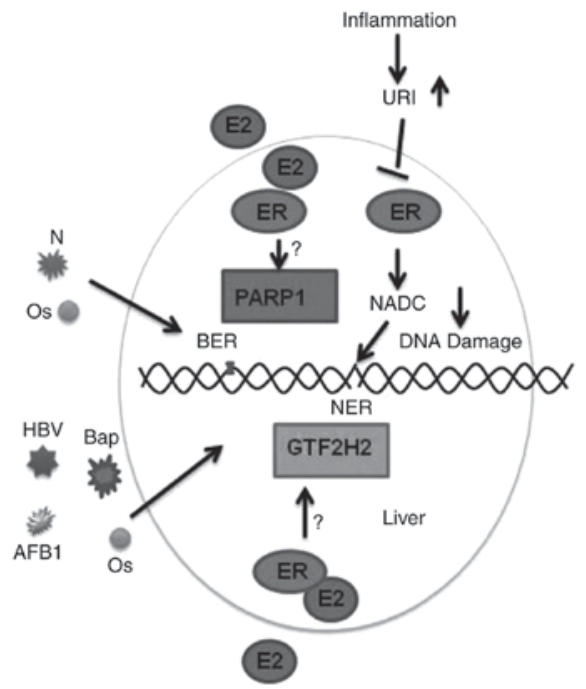

Figure 2. Estrogen may serve an inhibitory role in sex disparity in hepatocellular carcinoma via DNA repair. ER, estrogen receptor; E2, estradiol; PARP1, poly (ADP-ribose) polymerase 1; GTF2H2, general transcription factor IIH subunit 2; BER, base-excision repair; NER, nucleotide excision repair; URI, unconventional prefoldin RPB5 interactor; NADC, nicotinamide adenine dinucleotide; HBV, hepatitis B virus; Bap, benzo(a)pyrene; AFB1, aflatoxin B1; Os, oxidative stress markers.

PARP1, potentially disrupting host DNA damage repair (54). PARP-1 is downregulated in HBV-infected patients compared with uninfected controls (55). It has been reported that the physical interaction of hepatitis B virus X protein (HBX) and PARP1 accelerated DNA damage by inhibiting recruitment of the DNA repair complex to damaged DNA sites, which lead to hepatocarcinogenesis (47). In breast tissue, there is a positive association between PARP1 and ER expression (50). However, there are few studies on the association between ER and PARP1 in HCC, and this merits further exploration.

Transcription factor IIH. Research implies that HBX impedes the DNA repair process via its physical interactions with the helical components of TFIIH, including excision repair cross-complementing rodent repair deficiency, complementation groups 2 and 3 proteins (56). TFIIH is a multiprotein complex of 10 polypeptides and has clearly been shown to be an integral component of the DNA repair pathway $(57,58)$. Lee et al (59) reported the interaction of HBX with a probable cellular repair protein UV-damaged DNA-binding protein, which acts as an essential factor in HBV-associated hepatocarcinogenesis. General transcription factor IIH subunit (GTF2H) is located on 5q13.2 and encodes the 44-kDa RNA polymerase II TFIIH protein subunit 2 that interacts with other TFIIH subunits in the nucleotide excision repair pathway. Zhao et al (48) identified 30 (36.1\%) of 83 HCC cases with loss of heterogeneity at $5 \mathrm{q} 13.2$, in which the tumor-associated gene $G T F 2 H 2$ was present. GTF2H2 is an estrogen signaling pathway gene in breast cancer and is downregulated by luteolin (51). Therefore, the sex disparity in HCC partly attributed to $G T F 2 H 2$ is increasingly plausible.

Nicotinamide adenine dinucleotide (NADC). In the early stage of many types of cancer, including HCC, oncogene activation induces replication stress, resulting in DNA damage and chromosomal instability and acceleration of tumor development. Tummala et al (49) reported that increasing $\mathrm{NAD}^{+}$concentration is a critical mechanism in the prevention of HCC. They described that unconventional prefoldin RPB5 interactor (URI) inhibits the aryl hydrocarbon receptor (AhR) and ER-mediated transcription of enzymes implicated in $\mathrm{NAD}^{+}$ metabolism and synthesis, which causes DNA damage in the early stages of tumorigenesis (49). Djouder (60) proposed boosting $\mathrm{NAD}^{+}$as a strategy to prevent and cure $\mathrm{HCC}$ and revealed that the activation of AhR and ER was beneficial in HCC. Tummala et al (49) reported that AhR and ER could reverse URI-induced transcription of L-tryptophan/kynurenine catabolism and reduce the expression of tryptophan 2,3-dioxygenase through establishing AhR and ER knockout mice and conducting experiments in which AhR and ER were depleted in HepG2 cells. 


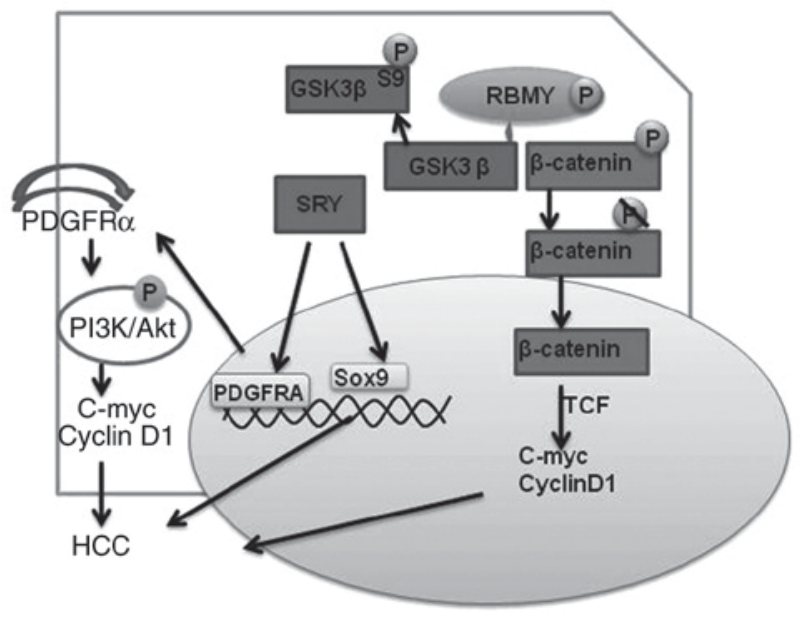

Figure 3. Y chromosome associated protein-coding genes are involved in HCC. SRY, sex-determining region on the Y chromosome; PDGFR $\alpha$, platelet-derived growth factor receptor $\alpha$; PI3K, phosphoinositide 3-kinase; RBMY, RNA-binding motif gene on the Y chromosome; GSK3 $\beta$, glycogen synthase kinase 3 $\beta$; TCF, T-cell factor; HCC, hepatocellular carcinoma.

Obesity. Unhealthy lifestyles including smoking and alcohol consumption are more prevalent among males compared with females, and are also speculated to be susceptibility factors for sex disparity of HCC (61). Obesity is a significant risk factor for certain types of cancer, including HCC $(61,62)$. Park et al $(63)$ described that both dietary and genetic obesity enhance the inflammation-dependent increase in IL- 6 and tumor necrosis factor expression and promote liver inflammation and tumorigenesis. Leptin, a $16 \mathrm{kD}$ protein hormone secreted by white adipose tissue, participates in the regulation of numerous physiological functions including atherosclerosis and carcinogenesis (64). Abnormal regulation of leptin-signaling serves a crucial role in obesity-associated liver cancer $(64,65)$. Shen and Shi (25) investigated the function of E2 in opposing oncogenic actions of leptin in HepG2 cells, which are poor host cells for supporting the replication of HBV or hepatitis $C$ virus. The researchers used small interfering-RNAs specific for ER- $\alpha, E R-\beta$ and G protein-coupled ER (GPER) to verify that E2 decreased activation of the leptin-signaling pathway through its receptors (25). E2 enhanced the activity of extracellular signal-regulated kinase via activation of ER- $\alpha$ and GPER and upregulated p38/MAPK via activation of $\operatorname{ER} \beta$. These responses reversed leptin-induced alterations, eventually inhibiting cell proliferation and stimulating cell apoptosis (25).

\section{Androgen/AR serves a role in promoting sex disparity in $\mathrm{HCC}$}

Androgens are male hormones that have been increasingly reported in male-predominant $\operatorname{HCC}(66,67)$. They are mainly involved in various physiological and pathological activities by combining with androgen receptors (ARs) $(68,69)$. A study by Wu et al (70) identified that overexpression of ARs enhanced HCC cell growth and invasion in vitro, and $\mathrm{HCC}$ initiation in vivo. Previous studies have reported higher androgen levels and more active androgen response elements (AREs) in liver tumor tissues, compared with control tissues $(8,71)$. Further investigation revealed that when male mice with AR knockout were induced by diethylnitrosamine (DEN), fewer tumors formed compared with wild-type mice (72). Androgen binding directly to AREs in the enhancer I of HBV genes activated the androgen-signaling pathway and increased the rate of HBV-induced hepatocarcinogenesis $(8,73)$. AR binding to ARE of the cell cycle related kinase promoter region controls activation of the $\beta$-catenin/T-cell factor signaling pathway, and has been identified as a major carcinogenic event and described in animal models and up to $90 \%$ of HCC cases (74). Ligand-stimulated AR upregulated miR-216a, resulting in tumorigenesis, and AR and miR-216a were concordantly over-expressed in clinical specimens (38). Both activity and secretion of aromatase, an enzyme which converts androgens to estrogens, was markedly increased in human HCC tissues and HepG2 cells $(75,76)$. This contradicts the protective effect of estrogen and promoting effect of androgen, and further studies are required to verify this observation.

\section{Sex chromosomes are involved in sex disparity in $\mathrm{HCC}$}

Previous studies have revealed that genetic alterations of chromosomes $\mathrm{X}$ and $\mathrm{Y}$ are frequently observed in patients with $\mathrm{HCC}$, including chromosome-specific gene change, oncogene and/or tumor suppressor gene expression and structural rearrangements of chromosomes $(9,11,77)$. This indicates that genes located on sex chromosomes may be responsible for HCC $(78,79)$.

X chromosome. X-chromosome-coupled zinc finger protein is abundantly expressed in HCC cells, and is associated with the proliferation and survival of tumor cells (77). In addition, mRNA and protein levels of dosage-sensitive sex reversal adrenal hypoplasia congenital critical region on $\mathrm{X}$ chromosome, gene 1 (DAX-1), are downregulated in HCC tissues and cell lines (10). DAX-1 is known for its fundamental roles in sex steroid-dependent neoplasms and interacts with $\beta$-catenin to attenuate its transcriptional activity $(80,81)$. Jiang et al $(10)$ first reported the role of the DAX-1/ $\beta$-catenin molecular network in controlling HCC development. Furthermore, it was revealed that DAX-1 is regulated by androgens (82).

$Y$ chromosome. Due to a lack of in vivo models, the impact of a small number of protein-coding genes in the $\mathrm{Y}$ chromosome remains largely unknown. Dysregulation of certain Y chromosome-specific genes, including RNA-binding motif gene on the $\mathrm{Y}$ chromosome and testis-specific protein Y-encoded $(83,84)$, have been identified in male HCC. Y chromosome associated protein-coding genes responsible for $\mathrm{HCC}$ are briefly illustrated in Fig. 3.

Sex-determining region on the Y chromosome (SRY). SRY has been recognized as an oncogene and cancer stem cell promoter in male $\mathrm{HCC}$ in in vitro studies $(85,86)$. Liu et al (9) reported overexpression of SRY in $\sim 84 \%$ of male patients with HCC. A liver-specific transgenic murine model with overexpression of SRY was susceptible to DEN-induced hepatocarcinogenesis compared with age- and sex-matched wild-type mice (9). SRY activates its downstream target SOX9 and the platelet-derived 
growth factor receptor $\alpha /$ phosphoinositide 3-kinase/protein kinase B pathway, which stimulates the expression of proliferation-associated genes $M Y C$ and cyclin D1 (CCND1), eventually accelerating tumorigenesis (9).

RNA binding motif protein Y-linked (RBMY). Oncogenic activation of RBMY is an important factor in hepatocarcinogenesis, and a marked increase of cytoplasmic and nuclear RBMY has been noted in HCC tissues $(11,87)$. The cytoplasmic expression of RBMY is associated with poor prognosis and decreased survival rate in patients with HCC (11). Cytoplasmic RBMY competes with the $\beta$-catenin destruction complex for binding GSK3b and enhancing the phosphorylation of glycogen synthase kinase $3 \beta$ Ser9 residue, which eventually induces nuclear entry of $\beta$-catenin for transcription of downstream oncogenes (11). The tumorigenicity of RBMY has also been demonstrated though its ability to induce cell transformation and tumor formation in nude mice, and RBMY transgenic mice exhibited an increased DEN-induced liver cancer incidence (83).

$Y$ chromosome loss and other genomic alterations. The genomic imbalances in HCC tissues have been studied mostly by comparative genomic hybridization $(\mathrm{CGH})(88,89)$. Y chromosome loss and other genomic alterations in HCC cell lines were analyzed by $\mathrm{CGH}$ and $\mathrm{CGH}$ array by Park et al (78). Park et al (78) detected the karyotypes of 21 male HCC cell lines and identified 18 HCC cell lines with Y chromosome loss, which may be responsible for the male preponderance in HCC. In addition, increased copy number of several genes, CCNDI and fibroblast growth factor 3/4 at 11q13, sarcoma amplified sequence/cyclin-dependent kinase 4 at 12q13, telomerase RNA component at $3 \mathrm{q} 26, M E T$ at $7 \mathrm{q} 31$, and $M Y C$ at $8 \mathrm{q} 24$, were identified in 20 primary HCC tissues (90).

\section{Conclusions}

HCC is characterized by an apparent sex disparity for which there lacks a clear mechanistic understanding. This current review summarized the recent research exploring the role of sex hormones and sex chromosomes in this process. Sex hormones and their receptors constitute two tumor-promoting and inhibiting axes through different channels. Genetic alterations in sex chromosomes could also contribute to the underlying mechanism of the sex disparity in HCC. In summary, the sex disparity in HCC is attributed to multiple mechanisms, and the targeting of both sex hormones and sex chromosomes is a novel and promising therapeutic approach for patients with HCC.

\section{Acknowledgements}

The authors would like to thank Dr Cathel Kerr for editing the English text of a draft of this manuscript.

\section{Funding}

The current study was supported by grants from the Nature Science Foundation of China (grant no. 81650014) and Beijing Natural Science Foundation (grant no. 7132058).

\section{Availability of data and materials}

The datasets used during the present study are available from the corresponding author upon reasonable request.

\section{Authors' contributions}

JH designed the study and revised it. YL, AX and SJ drafted the manuscript and revised the manuscript. All authors read and approved the manuscript and agree to be accountable for all aspects of the research in ensuring that the accuracy or integrity of any part of the work are appropriately investigated and resolved.

\section{Ethics approval and consent to participate}

This review does not contain any studies with human participants or animals performed by any of the authors.

\section{Patient consent for publication}

Not applicable.

\section{Competing interests}

The authors declare that they have no competing interests.

\section{References}

1. Torre LA, Bray F, Siegel RL, Ferlay J, Lortet-Tieulent J and Jemal A: Global cancer statistics, 2012. CA Cancer J Clin 65: 87-108, 2015.

2. Ascha MS, Hanouneh IA, Lopez R, Tamimi TA, Feldstein AF and Zein NN: The incidence and risk factors of hepatocellular carcinoma in patients with nonalcoholic steatohepatitis. Hepatology 51: 1972-1978, 2010.

3. El-Serag HB: Epidemiology of viral hepatitis and hepatocellular carcinoma. Gastroenterology 142: 1264-1273.e1, 2012.

4. Torre LA, Siegel RL, Ward EM and Jemal A: Global cancer incidence and mortality rates and trends-an update. Cancer Epidemiol Biomarkers Prev 25: 16-27, 2016.

5. Siegel RL, Miller KD and Jemal A: Cancer statistics, 2017. CA Cancer J Clin 67: 7-30, 2017.

6. Chen W, Zheng R, Baade PD, Zhang S, Zeng H, Bray F, Jemal A, Yu XQ and He J: Cancer statistics in China, 2015. CA Cancer J Clin 66: 115-132, 2016.

7. Naugler WE, Sakurai T, Kim S, Maeda S, Kim K, Elsharkawy AM and Karin M: Gender disparity in liver cancer due to sex differences in MyD88-dependent IL-6 production. Science 317: 121-124, 2007.

8. Wang SH, Yeh SH, Lin WH, Wang HY, Chen DS and Chen PJ: Identification of androgen response elements in the enhancer I of hepatitis B virus: A mechanism for sex disparity in chronic hepatitis B. Hepatology 50: 1392-1402, 2009.

9. Liu C, Ren YF, Dong J, Ke MY, Ma F, Monga SPS, Wu R, Lv Y and Zhang XF: Activation of SRY accounts for male-specific hepatocarcinogenesis: Implication in gender disparity of hepatocellular carcinoma. Cancer Lett 410: 20-31, 2017.

10. Jiang HL, Xu D, Yu H, Ma X, Lin GF, Ma DY and Jin JZ: DAX-1 inhibits hepatocellular carcinoma proliferation by inhibiting $\beta$-catenin transcriptional activity. Cell Physiol Biochem 34: 734-742, 2014.

11. Chua HH, Tsuei DJ, Lee PH, Jeng YM, Lu J, Wu JF, Su DS, Chen YH, Chien CS, Kao PC, et al: RBMY, a novel inhibitor of glycogen synthase kinase $3 \beta$, increases tumor stemness and predicts poor prognosis of hepatocellular carcinoma. Hepatology 62: 1480-1496, 2015.

12. Bertani S, Pineau P, Loli S, Moura J, Zimic M, Deharo E and Ruiz E: An atypical age-specific pattern of hepatocellular carcinoma in Peru: A threat for Andean populations. PLoS One 8: e67756, 2013. 
13. Hassan MM, Botrus G, Abdel-Wahab R, Wolff RA, Li D, Tweardy D, Phan AT, Hawk E, Javle M, Lee JS, et al: Estrogen replacement reduces risk and increases survival times of women with hepatocellular carcinoma. Clin Gastroenterol Hepatol 15: 1791-1799, 2017.

14. Yu MW, Chang HC, Chang SC, Liaw YF, Lin SM, Liu CJ, Lee SD, Lin CL, Chen PJ, Lin SC and Chen CJ: Role of reproductive factors in hepatocellular carcinoma: Impact on hepatitis B- and C-related risk. Hepatology 38: 1393-1400, 2003.

15. Bigsby RM and Caperell-Grant A: The role for estrogen receptor-alpha and prolactin receptor in sex-dependent DEN-induced liver tumorigenesis. Carcinogenesis 32: 1162-1166, 2011.

16. Prieto J: Inflammation, HCC and sex: IL- 6 in the centre of the triangle. J Hepatol 48: 380-381, 2008

17. Wang YC, Xu GL, Jia WD, Han SJ, Ren WH, Wang W, Liu WB, Zhang $\mathrm{CH}$ and Chen $\mathrm{H}$ : Estrogen suppresses metastasis in rat hepatocellular carcinoma through decreasing interleukin- 6 and hepatocyte growth factor expression. Inflammation 35: 143-149, 2012.

18. Coussens LM and Werb Z: Inflammation and cancer. Nature 420: 860-867, 2002

19. Karin M: Nuclear factor-kappaB in cancer development and progression. Nature 441: 431-436, 2006

20. Shi L, Feng Y, Lin H, Ma R and Cai X: Role of estrogen in hepatocellular carcinoma: Is inflammation the key? J Transl Med 12: 93, 2014.

21. Ren J, Chen GG, Liu Y, Su X, Hu B, Leung BC, Wang Y, Ho RL, Yang S, Lu G, et al: Cytochrome P450 1A2 metabolizes $17 \beta$-estradiol to suppress hepatocellular carcinoma. PLoS One 11: e0153863, 2016.

22. Zheng B, Zhu YJ, Wang HY and Chen L: Gender disparity in hepatocellular carcinoma (HCC): Multiple underlying mechanisms. Sci China Life Sci 60: 575-584, 2017.

23. Teng Y, Litchfield LM, Ivanova MM, Prough RA, Clark BJ and Klinge CM: Dehydroepiandrosterone-induces miR-21 transcription in HepG2 cells through estrogen receptor $\beta$ and androgen receptor. Mol Cell Endocrinol 392: 23-36, 2014.

24. Shen M, Cao J and Shi H: Effects of estrogen and estrogen receptors on transcriptomes of HepG2 Cells: A preliminary study using RNA sequencing. Int J Endocrinol 2018: 5789127 , 2018 .

25. Shen $\mathrm{M}$ and Shi H: Estradiol and estrogen receptor agonists oppose oncogenic actions of leptin in HepG2 cells. PLoS One 11: e0151455, 2016.

26. Pearce ST and Jordan VC: The biological role of estrogen receptors alpha and beta in cancer. Crit Rev Oncol Hematol 50: 3-22, 2004

27. Iyer JK, Kalra M, Kaul A, Payton ME and Kaul R: Estrogen receptor expression in chronic hepatitis $\mathrm{C}$ and hepatocellular carcinoma pathogenesis. World J Gastroenterol 23: 6802-6816, 2017.

28. Xu H, Wei Y, Zhang Y, Xu Y, Li F, Liu J, Zhang W, Han X, Tan R and Shen P: Oestrogen attenuates tumour progression in hepatocellular carcinoma. J Pathol 228: 216-229, 2012.

29. Wei Q, Guo P, Mu K, Zhang Y, Zhao W, Huai W, Qiu Y, Li T, Ma X, Liu Y, et al: Estrogen suppresses hepatocellular carcinoma cells through ER $\beta$-mediated upregulation of the NLRP3 inflammasome. Lab Invest 95: 804-816, 2015.

30. Hou J, Xu J, Jiang R, Wang Y, Chen C, Deng L, Huang X, Wang $X$ and Sun B: Estrogen-sensitive PTPRO expression represses hepatocellular carcinoma progression by control of STAT3. Hepatology 57: 678-688, 2013.

31. Yang W, Lu Y, Xu Y, Xu L, Zheng W, Wu Y, Li L and Shen P: Estrogen represses hepatocellular carcinoma (HCC) growth via inhibiting alternative activation of tumor-associated macrophages (TAMs). J Biol Chem 287: 40140-40149, 2012.

32. Deng L, Yang H, Tang J, Lin Z, Yin A, Gao Y, Wang X, Jiang R and Sun B: Inhibition of MTA1 by ER $\alpha$ contributes to protection hepatocellular carcinoma from tumor proliferation and metastasis. J Exp Clin Cancer Res 34: 128, 2015.

33. Lin YM, Velmurugan BK, Yeh YL, Tu CC, Ho TJ, Lai TY, Tsai CH, Tsai FJ, Tsai $\mathrm{CH}$ and Huang CY: Activation of estrogen receptors with E2 downregulates peroxisome proliferator-activated receptor $\gamma$ in hepatocellular carcinoma. Oncol Rep 30: 3027-3031, 2013.

34. Bartel DP and Chen CZ: Micromanagers of gene expression: The potentially widespread influence of metazoan microRNAs. Nat Rev Genet 5: 396-400, 2004
35. Amodio G, Sasso E, D'Ambrosio C, Scaloni A, Moltedo O, Franceschelli S, Zambrano N and Remondelli P: Identification of a microRNA (miR-663a) induced by ER stress and its target gene PLOD3 by a combined microRNome and proteome approach. Cell Biol Toxicol 32: 285-303, 2016

36. Sun L, Guo Z, Sun J, Li J, Dong Z, Zhang Y, Chen J, Kan Q and Yu Z: MiR-133a acts as an anti-oncogene in Hepatocellular carcinoma by inhibiting FOSL 2 through TGF- $\beta /$ Smad3 signaling pathway. Biomed Pharmacother 107: 168-176, 2018.

37. Ladeiro Y, Couchy G, Balabaud C, Bioulac-Sage P, Pelletier L, Rebouissou S and Zucman-Rossi J: MicroRNA profiling in hepatocellular tumors is associated with clinical features and oncogene/tumor suppressor gene mutations. Hepatology 47: 1955-1963, 2008

38. Chen PJ, Yeh SH, Liu WH, Lin CC, Huang HC, Chen CL, Chen DS and Chen PJ: Androgen pathway stimulates microRNA-216a transcription to suppress the tumor suppressor in lung cancer-1 gene in early hepatocarcinogenesis. Hepatology 56: 632-643, 2012.

39. Sun J, Lu H, Wang X and Jin H: MicroRNAs in hepatocellular carcinoma: Regulation, function, and clinical implications. ScientificWorldJournal 2013: 924206, 2013.

40. Marchesi F, Regazzo G, Palombi F, Terrenato I, Sacconi A, Spagnuolo M, Donzelli S, Marino M, Ercolani C, Di Benedetto A, et al: Serum miR-22 as potential non-invasive predictor of poor clinical outcome in newly diagnosed, uniformly treated patients with diffuse large B-cell lymphoma: An explorative pilot study. J Exp Clin Cancer Res 37: 95, 2018

41. Jiang R, Deng L, Zhao L, Li X, Zhang F, Xia Y, Gao Y, Wang X and Sun B: miR-22 promotes HBV-related hepatocellular carcinoma development in males. Clin Cancer Res 17: 5593-5603, 2011.

42. Liu WH, Yeh SH, Lu CC, Yu SL, Chen HY, Lin CY, Chen DS and Chen PJ: MicroRNA-18a prevents estrogen receptor-alpha expression, promoting proliferation of hepatocellular carcinoma cells. Gastroenterology 136: 683-693, 2009.

43. Li CL, Yeh KH, Liu WH, Chen CL, Chen DS, Chen PJ and Yeh SH: Elevated p53 promotes the processing of miR-18a to decrease estrogen receptor- $\alpha$ in female hepatocellular carcinoma. Int J Cancer 136: 761-770, 2015.

44. Luu-The V: Assessment of steroidogenesis and steroidogenic enzyme functions. J Steroid Biochem Mol Biol 137: 176-182, 2013.

45. Niu ZS, Niu XJ and Wang WH: Genetic alterations in hepatocellular carcinoma: An update. World J Gastroenterol 22: 9069-9095, 2016.

46. Aleksic K, Lackner C, Geigl JB, Schwarz M, Auer M, Ulz P, Fischer M, Trajanoski Z, Otte M and Speicher MR: Evolution of genomic instability in diethylnitrosamine-induced hepatocarcinogenesis in mice. Hepatology 53: 895-904, 2011.

47. Na TY, Ka NL, Rhee H, Kyeong D, Kim MH, Seong JK, Park YN and Lee MO: Interaction of hepatitis B virus X protein with PARP1 results in inhibition of DNA repair in hepatocellular carcinoma. Oncogene 35: 5435-5445, 2016.

48. Zhao Z, Chen GY, Long J, Li H and Huang J: Genomic losses at $5 q 13.2$ and 8p23.1 in dysplastic hepatocytes are common events in hepatitis B virus-related hepatocellular carcinoma. Oncol Lett 9: 2839-2846, 2015

49. Tummala KS, Gomes AL, Yilmaz M, Graña O, Bakiri L, Ruppen I, Ximénez-Embún P, Sheshappanavar V, Rodriguez-Justo M, Pisano DG, et al: Inhibition of de novo $\mathrm{NAD}(+)$ synthesis by oncogenic URI causes liver tumorigenesis through DNA damage. Cancer Cell 26: 826-839, 2014.

50. Mazzotta A, Partipilo G, De Summa S, Giotta F, Simone G and Mangia A: Nuclear PARP1 expression and its prognostic significance in breast cancer patients. Tumour Biol 37: 6143-6153, 2016.

51. Markaverich BM, Shoulars K and Rodriguez MA: Luteolin regulation of estrogen signaling and cell cycle pathway genes in MCF-7 human breast cancer cells. Int J Biomed Sci 7: 101-111, 2011.

52. Dantzer F, Schreiber V, Niedergang C, Trucco C, Flatter E, De La Rubia G, Oliver J, Rolli V, Ménissier-de Murcia J and de Murcia G: Involvement of poly(ADP-ribose) polymerase in base excision repair. Biochimie 81: 69-75, 1999

53. Song D, Huang H, Wang J, Zhao Y, Hu X, He F, Yu L and Wu J: NF90 regulates PARP1 mRNA stability in hepatocellular carcinoma. Biochem Biophys Res Commun 488: 211-217, 2017.

54. Ko HL and Ren EC: Novel poly (ADP-ribose) polymerase binding motif in hepatitis $\mathrm{B}$ virus core promoter impairs DNA damage repair. Hepatology 54: 1190-1198, 2011. 
55. Mukherjee RM, Shravanti GV, Jakkampudi A, Kota R, Jangala AL, Reddy PB, Rao PN, Gupta R and Reddy DN: Reduced expression of DNA damage repair genes high mobility group box1 and Poly(ADP-ribose) polymerase1 in inactive carriers of hepatitis B virus infection-A possible stage of viral integration. J Clin Exp Hepatol 3: 89-95, 2013.

56. Qadri I, Fatima K and AbdeL-Hafiz H: Hepatitis B virus X protein impedes the DNA repair via its association with transcription factor, TFIIH. BMC Microbiol 11: 48, 2011.

57. Hashimoto S and Egly JM: Trichothiodystrophy view from the molecular basis of DNA repair/transcription factor TFIIH. Hum Mol Genet 18: R224-R230, 2009.

58. Schärer OD: Hot topics in DNA repair: The molecular basis for different disease states caused by mutations in TFIIH and XPG. DNA Repair (Amst) 7: 339-344, 2008

59. Lee TH, Elledge SJ and Butel JS: Hepatitis B virus X protein interacts with a probable cellular DNA repair protein. J Virol 69: 1107-1114, 1995.

60. Djouder N: Boosting NAD(+) for the prevention and treatment of liver cancer. Mol Cell Oncol 2: e1001199, 2015.

61. Boniol M and Autier P: Prevalence of main cancer lifestyle risk factors in Europe in 2000. Eur J Cancer 46: 2534-2544, 2010.

62. Grohmann M, Wiede F, Dodd GT, Gurzov EN, Ooi GJ, Butt T, Rasmiena AA, Kaur S, Gulati T, Goh PK, et al: Obesity drives STAT-1-dependent NASH and STAT-3-dependent HCC. Cell 175: 1289-1306 e20, 2018.

63. Park EJ, Lee JH, Yu GY, He G, Ali SR, Holzer RG, Osterreicher $\mathrm{CH}$, Takahashi $\mathrm{H}$ and Karin M: Dietary and genetic obesity promote liver inflammation and tumorigenesis by enhancing IL-6 and TNF expression. Cell 140: 197-208, 2010.

64. Xiong Y, Zhang J, Liu M, An M, Lei L and Guo W: Human leptin protein activates the growth of HepG2 cells by inhibiting PERK-mediated ER stress and apoptosis. Mol Med Rep 10 $1649-1655,2014$

65. Vansaun MN, Mendonsa AM and Lee Gorden D: Hepatocellular proliferation correlates with inflammatory cell and cytokine changes in a murine model of nonalchoholic fatty liver disease. PLoS One 8: e73054, 2013.

66. Li S, Mo C, Huang S, Yang S, Lu Y, Peng Q, Wang J, Deng Y, Qin $X$ and Liu Y: Over-expressed Testis-specific Protein Y-encoded 1 as a novel biomarker for male hepatocellular carcinoma. PLoS One 9: e89219, 2014.

67. Montella M, D'Arena G, Crispo A, Capunzo M, Nocerino F, Grimaldi M, Barbieri A, D'Ursi AM, Tecce MF, Amore A, et al: Role of sex hormones in the development and progression of hepatitis B virus-associated hepatocellular carcinoma. Int J Endocrinol 2015: 854530, 2015.

68. Beato M and Klug J: Steroid hormone receptors: An update. Hum Reprod Update 6: 225-236, 2000.

69. Chang CS, Kokontis J and Liao ST: Molecular cloning of human and rat complementary DNA encoding androgen receptors Science 240: 324-326, 1988.

70. Wu MH, Ma WL, Hsu CL, Chen YL, Ou JH, Ryan CK, Hung YC, Yeh S and Chang C: Androgen receptor promotes hepatitis B virus-induced hepatocarcinogenesis through modulation of hepatitis B virus RNA transcription. Sci Transl Med 2: 32ra35, 2010.

71. Barone M, Margiotta M, Scavo MP, Gentile A, Francioso D, Papagni S, Castellaneta A, Mallamaci R, Di Leo A and Francavilla A: Possible involvement of androgen receptor alterations in hepatocarcinogenesis. Dig Liver Dis 41: 665-670, 2009

72. Ma WL, Hsu CL, Wu MH, Wu CT, Wu CC, Lai JJ, Jou YS, Chen $\mathrm{CW}$, Yeh $\mathrm{S}$ and Chang $\mathrm{C}$ : Androgen receptor is a new potential therapeutic target for the treatment of hepatocellular carcinoma. Gastroenterology 135: 947-955, 955.e1-5, 2008.

73. Yang WJ, Chang CJ, Yeh SH, Lin WH, Wang SH, Tsai TF, Chen DS and Chen PJ: Hepatitis B virus X protein enhances the transcriptional activity of the androgen receptor through c-Src and glycogen synthase kinase-3beta kinase pathways. Hepatology 49: 1515-1524, 2009.
74. Feng H, Cheng AS, Tsang DP, Li MS, Go MY, Cheung YS, Zhao GJ, Ng SS, Lin MC, Yu J, et al: Cell cycle-related kinase is a direct androgen receptor-regulated gene that drives $\beta$-catenin/T cell factor-dependent hepatocarcinogenesis. J Clin Invest 121: 3159-3175, 2011.

75. Koh WP, Yuan JM, Wang R, Govindarajan S, Oppenheimer R, Zhang ZQ, Yu MC and Ingles SA: Aromatase (CYP19) promoter gene polymorphism and risk of nonviral hepatitis-related hepatocellular carcinoma. Cancer 117: 3383-3392, 2011.

76. Castagnetta LA, Agostara B, Montalto G, Polito L, Campisi I, Saetta A, Itoh T, Yu B, Chen S and Carruba G: Local estrogen formation by nontumoral, cirrhotic, and malignant human liver tissues and cells. Cancer Res 63: 5041-5045, 2003.

77. Zhang S, Shu R, Yue M and Zhang S: Effect of over-expression of zinc-finger protein (ZFX) on self-renewal and drug-resistance of hepatocellular carcinoma. Med Sci Monit 22: 3025-3034, 2016.

78. Park SJ, Jeong SY and Kim HJ: Y chromosome loss and other genomic alterations in hepatocellular carcinoma cell lines analyzed by CGH and CGH array. Cancer Genet Cytogenet 166: 56-64, 2006.

79. Liu J, Wang ZM, Zhen SF, Wu XP, Ma DX, Li ZH, Liu B, Zhao ZL and $\mathrm{Ke} Y$ Y: Aberration of $\mathrm{X}$ chromosome in liver neoplasm detected by fluorescence in situ hybridization. Hepatobiliary Pancreat Dis Int 3: 110-114, 2004.

80. Lalli E and Alonso J: Targeting DAX-1 in embryonic stem cells and cancer. Expert Opin Ther Targets 14: 169-177, 2010.

81. Li H, Zhang Z, Bi Y, Yang D, Zhang L and Liu J: Expression characteristics of $\beta$-catenin in scallop Chlamys farreri gonads and its role as a potential upstream gene of Dax1 through canonical Wnt signalling pathway regulating the spermatogenesis. PLoS One 9: e115917, 2014.

82. Campbell DEK and Langlois VS: Expression of sf1 and dax-1 are regulated by thyroid hormones and androgens during Silurana tropicalis early development. Gen Comp Endocrinol 259: 34-44, 2018.

83. Tsuei DJ, Lee PH, Peng HY, Lu HL, Su DS, Jeng YM, Hsu HC, Hsu SH, Wu JF, Ni YH and Chang MH: Male germ cell-specific RNA binding protein RBMY: A new oncogene explaining male predominance in liver cancer. PLoS One 6: e26948, 2011.

84. Yin YH, Li YY, Qiao H, Wang HC, Yang XA, Zhang HG, Pang XW, Zhang Y and Chen WF: TSPY is a cancer testis antigen expressed in human hepatocellular carcinoma. Br J Cancer 93: 458-463, 2005

85. Murakami S, Chishima S, Uemoto H, Sakamoto E, Sato T, Kurabe N, Kawasaki Y, Shibata T, Akiyama H and Tashiro F: The male-specific factor Sry harbors an oncogenic function. Oncogene 33: 2978-2986, 2014.

86. Murakami S, Ninomiya W, Sakamoto E, Shibata T, Akiyama H and Tashiro F: SRY and OCT4 are required for the acquisition of cancer stem cell-like properties and are potential differentiation therapy targets. Stem Cells 33: 2652-2663, 2015.

87. Tsuei DJ, Hsu HC, Lee PH, Jeng YM, Pu YS, Chen CN, Lee YC, Chou WC, Chang CJ, Ni YH and Chang MH: RBMY, a male germ cell-specific RNA-binding protein, activated in human liver cancers and transforms rodent fibroblasts. Oncogene 23: 5815-5822, 2004

88. Homayounfar K, Schwarz A, Enders C, Cameron S, Baumhoer D, Ramadori G, Lorf T, Gunawan B and Sander B: Etiologic influence on chromosomal aberrations in European hepatocellular carcinoma identified by CGH. Pathol Res Pract 209: 380-387, 2013.

89. Hashimoto K, Mori N, Tamesa T, Okada T, Kawauchi S, Oga A, Furuya T, Tangoku A, Oka M and Sasaki K: Analysis of DNA copy number aberrations in hepatitis $\mathrm{C}$ virus-associated hepatocellular carcinomas by conventional CGH and array CGH. Mod Pathol 17: 617-622, 2004.

90. Takeo S, Arai H, Kusano N, Harada T, Furuya T, Kawauchi S, Oga A, Hirano T, Yoshida T, Okita K and Sasaki K: Examination of oncogene amplification by genomic DNA microarray in hepatocellular carcinomas: Comparison with comparative genomic hybridization analysis. Cancer Genet Cytogenet 130: 127-132, 2001. 